\title{
Effectiveness of the Blended Learning Model to Improve Students' Achievement of Mathematical Concepts
}

\author{
Dewi Indrapangastuti ${ }^{\rtimes}$ \\ Herman Dwi Surjono ${ }^{2}$ \\ Sugiman $^{3}$ (D) \\ Bagus Endri Yanto ${ }^{4}$
}

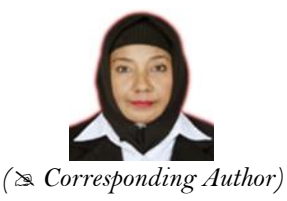

${ }^{1,2, s}$ Faculty of Mathematics and Natural Sciences, Universitas Negeri Yogyakarta, Indonesia.

IEmail: dindrapangastuti@gmail.com Tel: +6281326910105

EEmail: hermansurjono@uny.ac.id Tel:+6282134613100

"Email:sugiman@uny.ac.id Tel:+628122786314.

${ }^{4}$ Faculty of Tarbiyah and Tadris, State Islamic Institute of Bengkulu, Indonesia.

Email:bagus@iainbengkulu.ac.id +6285268337993

Abstract

This study aims to discover the effectiveness of the blended learning model in mathematics learning to improve the achievement of mathematical concepts. This study employed a quasiexperimental design with a non-equivalent control group. The experimental class was taught through blended learning, while the control class was taught through the conventional learning model. The population of this study was the students at State Senior High School 1 Sewon Yogyakarta, Indonesia. The research sample involved 60 tenth-grade students in the 2019/2020 academic year, 30 students in each of the experimental and control groups. The sampling technique used cluster sampling and the data were collected using a test instrument. The validity of the test was measured using the obtained Aiken index (0.80), and the reliability was based on the Cronbach's alpha coefficient (0.86). The data were analyzed using t-tests and descriptive statistics. The results of this study showed that the blended learning model is significantly more effective than the conventional learning model in enhancing students' achievement of mathematical concepts. This means that the application of blended learning in mathematics learning can significantly improve students' achievement of mathematical concepts.

Keywords: Blended learning, Mathematics learning, Mathematical concepts achievement, Trigonometry, Contextual learning, Senior high school.

Citation | Dewi Indrapangastuti; Herman Dwi Surjono; Sugiman; Bagus Endri Yanto (2021). Effectiveness of the Blended Learning Model to Improve Students' Achievement of Mathematical Concepts. Journal of Education and e-Learning Research, 8(4): 423Conction 430.

History:

Received: 6 September 2021

Revised: 12 November 202

Accepted: 9 December 2021

Published: 27 December 202

Licensed: This work is licensed under a Creative Commons

Attribution 3.0 License $(\mathrm{cc})$ EY

Publisher: Asian Online Journal Publishing Group
Acknowledgement: All authors contributed to the conception and design of the study.

Funding: This study received no specific financial support.

Competing Interests: The authors declare that they have no conflict of interests.

Transparency: The authors confirm that the manuscript is an honest, accurate, and transparent account of the study was reported; that no vital features of the study have been omitted; and that any discrepancies from the study as planned have been explained.

Ethical: This study follows all ethical practices during writing.

\section{Contents}

1. Introduction

2. Method

3. Participants

4. Data Collection...........426

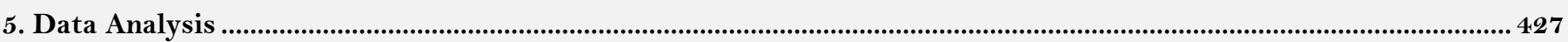

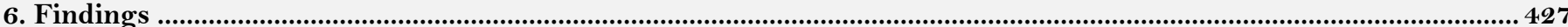

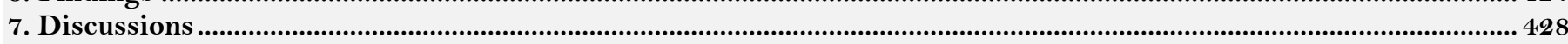

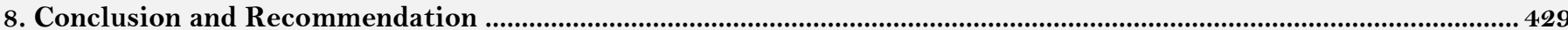

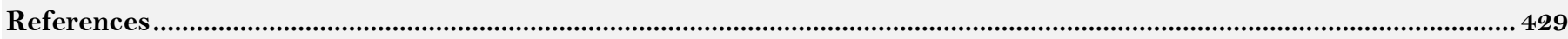




\section{Contribution of this paper to the literature}

This study contributes to the existing literature by applying the blended learning model, which is based on the belief that students can best develop their thinking skills through problembased learning from various sources.

\section{Introduction}

Technological advances should be integrated in the learning process to successfully further students' learning outcomes. Various learning models allow teachers to take advantage of technological developments to improve students' skills and competencies (Hermino \& Arifin, 2020). In the context of the Fourth Industrial Revolution, teachers must use current technology to create new learning models. Innovative learning strategies that integrate appropriate methods, media, and basic competencies are crucial to fulfilling the demands of the future. The application of varied and innovative methods will improve students' motivation and self-awareness to achieve the learning goals (Ramadhan, Chaeruman, \& Kustandi, 2018). This is an indicator of the importance of teachers' technological literacy related to their knowledge and skills in utilizing technology in the learning process (Tican \& Deniz, 2019). The use of appropriate learning models, including a technology-based learning model, is beneficial to improving learning outcomes, (Arsyad, 2016). The choice of learning model must be well planned to effectively improve students' learning achievement, especially in the case of mathematics, which is commonly identified as one of the most difficult subjects (Tohir, Maswar, Atikurrahman, Saiful, \& Pradita, 2020).

Mathematics is a universal science that underlies the development of modern technology and plays an important role in various disciplines and human thinking (Sadiq, 2014). The mastery of mathematical concepts from an early age is very necessary, but most students find it difficult to understand abstract mathematical concepts (Manfreda \& Hodnik, 2021). Professional teachers can teach mathematical concepts in context (Saka, 2021), which makes the study of mathematics require creative thinking to solve problems (Chasanah, Riyadi, \& Usodo, 2020). However, the results of the Program for International Student Assessment (PISA) survey show that Indonesian students have low mathematical literacy compared to students from other countries.

A common problems in teaching mathematics is students' difficulty in understanding the subject, especially the mathematical concepts, their meaning, and use. Retnawati, Kartowagiran, Hadi, and Hidayati (2011) reveal that as many as $88.57 \%$ of students have difficulties absorbing the mathematics material that should be mastered. Waskitoningtyas (2016) outlines several factors that cause students to experience difficulties in learning mathematics, including low attraction to math, the necessity of memorizing many formulas, a lack of teaching aids, monotonous methods, and a lack of teachers' attention for students with low levels of understanding. Moreover, the findings of Kurniadi, Mardiyana, and Riyadi (2014) suggest that in general many errors in completing mathematics exercises exacerbate students' difficulties.

Math learning can be made fun if the teachers have sufficient knowledge of the aspects that support success in learning, such as effective learning theories, models, strategies, methods, and media. The active learning process is characterized by students' physical, mental, and emotional involvement. This should be achieved by developing and utilizing a learning model that helps teachers overcome students' learning difficulties. Effective mathematics teaching requires a technology-based learning model, not just the lecturing method. Johnson and Walker (2011) noted that students have a positive attitude towards the use of technology for mathematics learning. In today's digital era, the majority of high school students is accustomed to utilizing information and communication technology (ICT) in their daily lives, but unfortunately the use of the internet in learning is not yet at an effective level to support learning activities. Therefore, online learning should be increased. This learning system can also overcome limitations of class time, since students can access the web, download the material, and discuss or chat with teachers or peers at any time. According to Kazu and Demirkol (2014), students who have studied in a combined online and face-to-face learning environment are achieving better learning outcomes. Ross and Bruce (2009) also emphasized that the development of effective learning methods both on- and offline requires continuous effort to overcome student learning difficulties.

The use of the internet can benefit both teachers and students during the learning process (Darmawan, 2016; Singhal, 2017). Learning through the internet helps students take a more active role in learning without any constraints of space and time (Suartama et al., 2020). To accommodate these benefits, the blended learning model offers an appropriate learning model to improve students' achievement of mathematical concepts. The blended learning model is suitable for trigonometric material, where it allows students to learn through face-to-face, practical activities, and online learning. During face-to-face learning, students can discuss the material directly with teachers and peers, and they can practice the material from the media during their practical activities. Students can also study materials any time in the form of e-books, pdfs, powerpoints, or videos, and complete online test items in the learning management system.

Based on the results of our preliminary observations, it was found that due to the lack of technology integration in learning, for example during trigonometric learning, students tended to memorize many formulas yet did not develop the trigonometric concept. The teachers also conveyed concepts through expository learning without making optimal use of the existing learning models. Many schools have been outfitted with computer laboratories and adequate $\mathrm{Wi}-\mathrm{Fi}$ coverage, but it is rare for these to be integrated into the learning process; most teachers fail to channel these ICT sources to support their teaching. However, it is important for students to achieve an understanding of mathematical concepts by utilizing ICT and innovative learning resources and media to provide meaningful contexts for problem solving activities (Suyanto \& Asep, 2013). Thus, this study aims to solve students' problems with learning mathematical concepts by applying a blended learning model involving technology integration. Specifically, this study uses a blended learning model to improve tenth-grade students' achievement of mathematical concepts in trigonometry. The blended learning model, that has been widely implemented, combines classroom interaction and online learning (Miyaji \& Fukui, 2020). This study has also added field practice through video tutorials in e-learning programs to the model, to make it easier for students to practice trigonometric concepts. The experience gained during the trigonometry practice in the surrounding environment is expected to reduce the abstractness of the concepts so that the learning process becomes more 
meaningful. The academic success of students who have studied in online learning environments as well as face-toface learning environments shows simultaneous escalation (Kazu \& Demirkol, 2014). Furthermore, Uz and Uzun (2018) found that the development of effective learning sequences, both online and offline, requires continuous effort to effectively overcome students' learning difficulties. In e-learning, students can use smartphones and computers as digital media (Liu \& Hwang, 2010). Based on the results of the studies mentioned above, it is clear that an integrated blended learning model is ideal for this study. Jeffrey, Milne, Suddaby, and Higgins (2014) noted that an important aspect of developing a blended learning model is the integration of the online and classroom components. This means that blended learning is achieved by combining classroom and online learning as an integrated, technological learning innovation. Cheung and Hew (2011) argued that blended learning is a learning model that combines synchronous and asynchronous learning, where the synchronous learning is conducted at the same time and at either the same or different places, while asynchronous learning is at different times and places. The blended learning model in this study includes (1) live, synchronous, face-to-face learning using discussion, practice, and presentation strategies; (2) virtual synchronous learning, in which students and teachers can chat through e-learning programs during independent learning time; (3) independent asynchronous learning, in which students learn independently whether at school or at home (or anywhere) by accessing material in the e-learning program; and (4) asynchronous collaboration, in which students can discuss the material on discussion forums in the e-learning program. The blended learning model developed in this study combines three learning methods, namely face-to-face learning, practice, and online learning. The face-to-face learning combines discussion and presentation strategies, after which the students are given opportunities to practice in groups in the surrounding school environment. The practice consists of using a simple clinometer model made by the students. Meanwhile, the online learning session is conducted through the Moodle e-learning platform. The use of blended learning is very beneficial for students. As mentioned by Tuomainen (2016), the blended learning model can trigger students' enthusiasm for learning and improve their time management, as well as encourage students to be more independent and responsible. The previous study conducted by Mozelius and Hettiarachchi (2017) clarified that a combination of blended learning methods is better than a single model. In line with this, Albhnsawy and Aliweh (2016) admitted that blended learning activities offer many opportunities for teachers and students to receive feedback and exchange views. Similarly, Behjat, Yamini, and Bagheri (2012) agreed that students have broader access to learning resources in the blended learning model. According to Wardani, Toenliou, and Wedi (2018), a blended learning model can increase the attractiveness of the learning process and is very suitable for learning in the 21st century. Surjono, Muhtadi, and Wahyuningsih (2017) claimed that blended learning provides more benefits for students in terms of their achievement and higher levels of participation, compared to traditional faceto-face learning. Most students also have a positive attitude towards the application of blended learning. Referring to previous studies, this study has been designed to compensate for the limitations of previous research. The findings of several preceding studies have shows that blended learning offers significant improvement in students' learning outcomes and positive attitudes towards learning. However, no research has been previously carried out on the application of a blended learning model that combines three learning methods, i.e., face-to-face, online, and practical activities. Besides, no prior blended learning model has been based on three learning theories: cognitive, constructivism, and pragmatism. This study applies a blended learning model that combines those three learning methods, based on the three learning theories, to enhance tenth-grade students' achievement of the mathematical concepts of trigonometry. Based on the background and problems described above, teachers must understand how to integrate the content and explain the various mathematical concepts through the application of technology in the blended learning model. Therefore, the study's research question can be formulated as: how effective is the blended learning model in improving students' achievement of mathematical concepts?

\section{Method}

Table-1. The syntax of the blended learning model.

\begin{tabular}{|c|c|c|c|}
\hline \multirow[t]{2}{*}{ Learning stages } & \multicolumn{2}{|l|}{ Activities } & \multirow[t]{2}{*}{ Explanation } \\
\hline & Teachers & Students & \\
\hline \multirow[t]{7}{*}{ Orientation } & Conveying the learning objectives & $\begin{array}{l}\text { Reading and understanding } \\
\text { the learning objectives }\end{array}$ & Face-to-face \\
\hline & $\begin{array}{l}\text { Giving apperceptions about right triangles, } \\
\text { Pythagoras, and trigonometric ratios }\end{array}$ & Answering teacher questions & Face-to-face \\
\hline & $\begin{array}{l}\text { Motivating students about the importance of } \\
\text { learning trigonometric ratios }\end{array}$ & Paying attention & Face-to-face \\
\hline & Giving a pretest & Completing the pretest & Face-to-face \\
\hline & $\begin{array}{l}\text { Providing instructions on how to } \log \text { in to the e- } \\
\text { learning platform }\end{array}$ & $\begin{array}{l}\text { Logging in to the e-learning } \\
\text { platform }\end{array}$ & Online \\
\hline & Introducing the material on trigonometric ratios & $\begin{array}{l}\text { Understanding the material on } \\
\text { trigonometric ratios through } \\
\text { e-learning }\end{array}$ & Online \\
\hline & Providing a $\mathrm{Q}$ and $\mathrm{A}$ session & $\mathrm{Q}$ and $\mathrm{A}$ & Online \\
\hline Organization & $\begin{array}{l}\text { Giving assignments to stimulate group } \\
\text { discussion }\end{array}$ & $\begin{array}{l}\text { Accessing and downloading } \\
\text { the assignments for group } \\
\text { discussion }\end{array}$ & Online \\
\hline \multirow[t]{2}{*}{ Investigation } & $\begin{array}{l}\text { Providing an opportunity to explore the existing } \\
\text { e-learning material }\end{array}$ & Exploring e-learning material & Online \\
\hline & Providing opportunities for group discussion & Discussing group assignments & Face-to-face \\
\hline Presentation & $\begin{array}{l}\text { Giving the opportunity to present the results of } \\
\text { group assignments }\end{array}$ & $\begin{array}{l}\text { Presenting the results of group } \\
\text { assignments }\end{array}$ & Face-to-face \\
\hline \multirow[t]{3}{*}{ Analysis and Evaluation } & $\begin{array}{l}\text { Reflecting the results of the presentation / } \\
\text { group assignment }\end{array}$ & $\begin{array}{l}\text { Reflecting the results of the } \\
\text { presentation } \\
\text { assignment }\end{array}$ & Face-to-face \\
\hline & Guiding students to conclude the material & Concluding the material & Face-to-face \\
\hline & Giving a posttest & Completing the posttest & Online \\
\hline
\end{tabular}


This study employed a quasi-experimental design with a non-equivalent control group to compare the development of the achievement of mathematical concepts between the experimental and the control class. The experimental class was taught using the blended learning model, while the control class was taught using the conventional model. This research was conducted over the course of two months from May to June 2019. The stages of learning activities in the implementation of the blended learning model are presented in Table 1.

The flowchart to guide the navigation of the developed learning model can be seen in Figure 1.

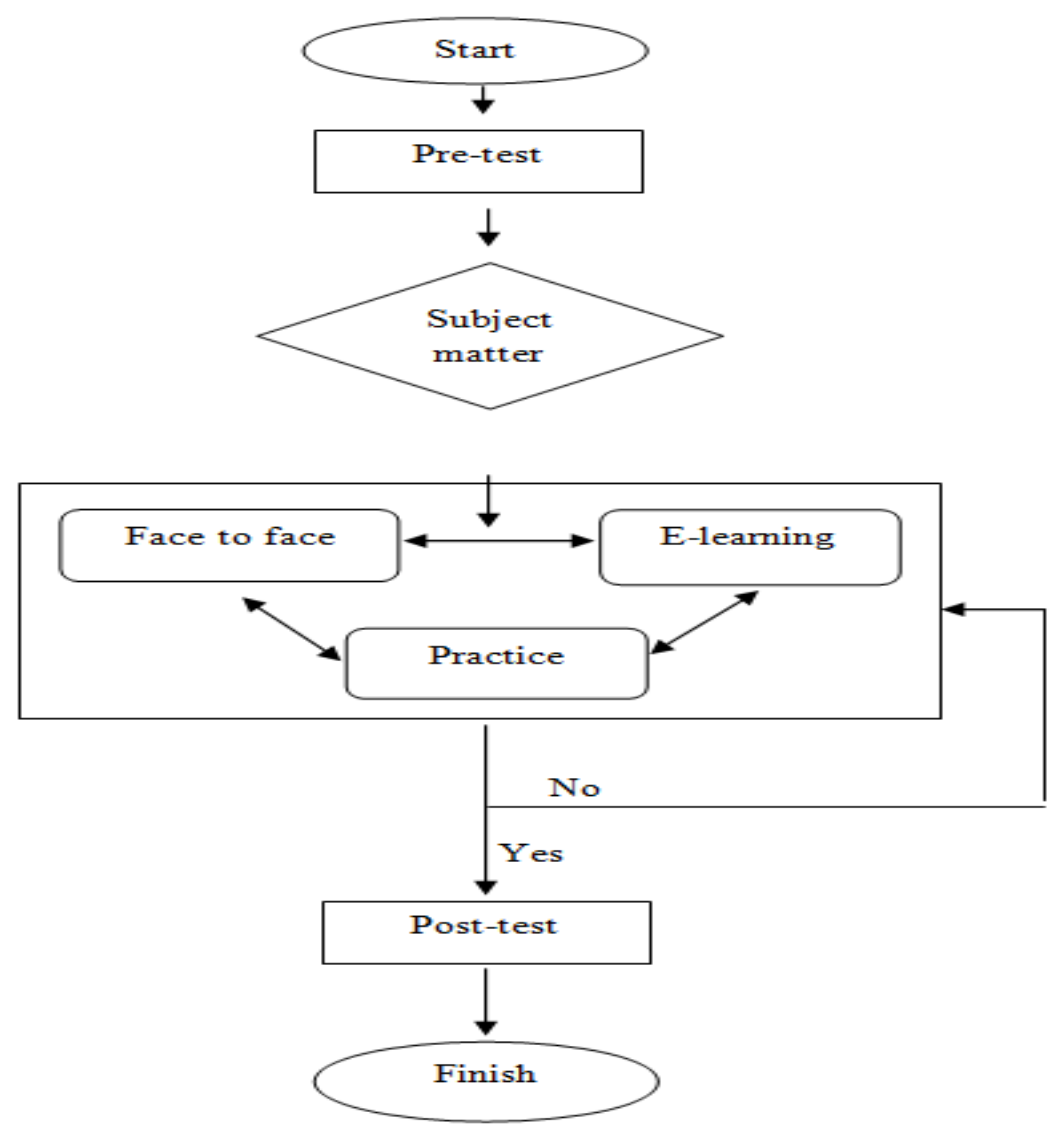

Figure-1. The flowchart of the blended learning model.

\section{Participants}

The population of this study involved students at State Senior High School 1 Sewon Yogyakarta, Indonesia. The research sample involved 60 tenth grade students in the 2019/2020 academic year, of which 30 students were in the experimental group and 30 in the control group. The sampling technique used in this study was cluster sampling, where the samples were taken based on predetermined groups (Sugiyono, 2015).

\section{Data Collection}

The data was collected using a test to measure students' achievement of mathematics concepts. The purpose of the test instrument is to obtain an overview of the students' achievement level of math concepts that can be used to judge the effectiveness of the learning model. Specifically, the test evaluates students' basic competence with trigonometric ratios material (sine, cosine, tangent, cosecant, secant, and cotangent) in a right triangle, as well as contextual problems related to trigonometric ratios (sine, cosine, tangent, cosecant, secant, and cotangent) in a right triangle. This test was administered to students before the learning process (pretest) and after the learning implementation (posttest). The following Table 2 shows the test instrument guidelines to obtain data on the achievement of mathematical concepts.

Table-2. Test instrument guidelines on the achievement of the mathematical concepts

\begin{tabular}{|c|c|c|c|}
\hline Basic competencies & Indicators & Item number & Test form \\
\hline \multirow{6}{*}{$\begin{array}{l}\text { Trigonometric ratios (sine, } \\
\text { cosine, tangent, cosecant, } \\
\text { secant, and cotangent) in a } \\
\text { right triangle }\end{array}$} & Determining the sine value of an angle in a right triangle & 2 & Checklist \\
\hline & Determining the cosine of an angle in a right triangle & 1 & Checklist \\
\hline & $\begin{array}{l}\text { Determining the tangent value of an angle on a right } \\
\text { triangle }\end{array}$ & 2 & Checklist \\
\hline & $\begin{array}{l}\text { Determining the cotangent value of an angle on a right } \\
\text { triangle }\end{array}$ & 1 & Checklist \\
\hline & $\begin{array}{l}\text { Determining the secant value of an angle in a right } \\
\text { triangle }\end{array}$ & 2 & Checklist \\
\hline & $\begin{array}{l}\text { Determining the cosecant value of an angle on a right } \\
\text { triangle }\end{array}$ & 2 & Checklist \\
\hline
\end{tabular}

This research instrument was declared valid by measuring the expert agreement index based on the Aiken index $(\mathrm{V})$. The measurement results revealed an Aiken index coefficient of 0.80 , which was considered valid. Meanwhile, the instrument reliability was determined using the Cronbach's alpha coefficient, which resulted in a score of 0.86 , so it can be categorized as highly reliable (Taber, 2018). 


\section{Data Analysis}

The results of this study were analyzed using quantitative descriptive statistics with the Statistical Package for Social Sciences (SPSS) for Windows version 22. The Shapiro-Wilk One-Sample Test was conducted to determine the normality of the data and the Levene test to check the homogeneity. Furthermore, a t-test was performed to determine any significant differences in the mean scores between the experimental and the control class.

\section{Findings}

6.1 Realization of e-Learning

E-learning was conducted using Moodle and included materials for each topic, media, assignments, discussion forums, and test items. The e-learning platform can be accessed through https://dewi-indrapangastuti.about.my.id as shown in Figure 2 below.

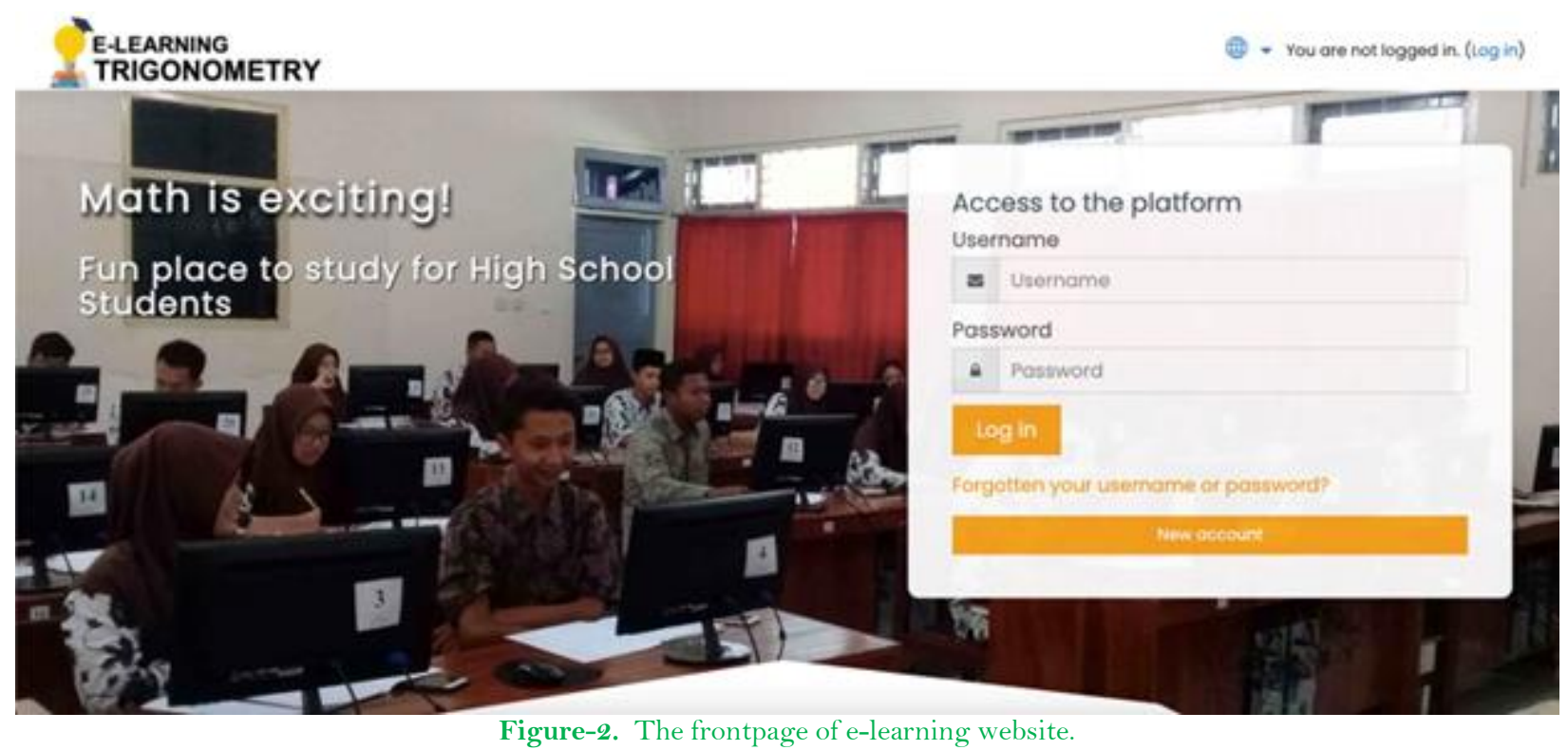

The website in Figure 2 appears when the e-learning users open the website. They are then requested to $\log$ in. The home page of the website can be seen in Figure 3:

\section{E-LEARNING}

TRIGONOMETRY

(16) - You are not logged in (log in)

\section{Welcome to Online Learning Trigonometry Course}

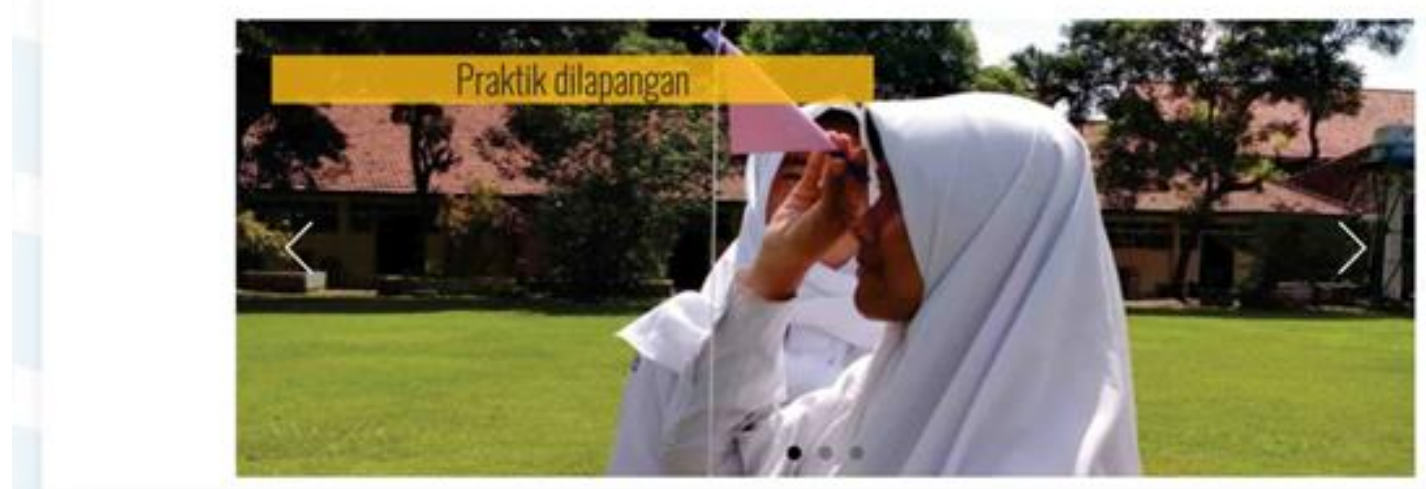

Figure-3. The e-learning homepage.

The home page shows images of group discussions in face-to-face learning, online learning, and field practice, to show the activities of the learning process at a glance. Figure 3 above shows one example of the practical activities that are included in the lesson, i.e., measuring the height of the flagpole in the schoolyard using a simple clinometer. The instruction for this activity includes guidelines for making a simple clinometer and how to use it and is delivered by means of a video in the e-learning program.

\subsection{The Effectiveness of the Blended Learning Model Implementation}

The effectiveness of the blended learning model is determined based on its effects on students' mastery of mathematical concepts. The blended learning model is considered effective if it can improve students' understanding of mathematical concepts. In the initial test stage, normality and homogeneity tests were performed. The significance value of the normality test was determined using the Kolmogorov-Smirnov test. The normality test results were 0.261 and 0.325 for the experimental and control classes, respectively. The significance value of each was greater than 0.05 , so it can be concluded that the data were normally distributed. The results of the homogeneity test revealed that the Levene Test value was 0.312 with a sig. value of 0.579 . The p-value was greater than 0.05 , thus Ho was accepted; it can therefore be concluded that the experimental group and the control group population have the same variance. Finally, the effectiveness of the blended learning model, based on the achievement of mathematical concepts, can be seen from the analysis results of the value difference between the 
normalized gain scores and the t-test. The learning outcomes with regard to the achievement of understanding of mathematical concepts is presented in Table 3 below.

\begin{tabular}{c|c|c}
\multicolumn{2}{c}{ Table-3. The data analysis of the n-gain scores of students' problem-solving skills. } \\
\hline Data & Experiment Class & Control Class \\
\hline The number of students & 30 & 30 \\
\hline Mean & 82.54 & 58.74 \\
\hline Std. deviation & 16.56 & 13.28 \\
\hline Minimum & 45.00 & 35.00 \\
\hline Maximum & 81.82 & 64.77 \\
\hline Criteria & Effective & Less Effective \\
\hline
\end{tabular}

Table 3 shows that the $\mathrm{N}$-gain score for the experimental class was 82.54 or $82 \%$, which can be categorized as effective. In contrast, the N-gain score for the control class was $58.74 \%$ or $58 \%$, which may be considered less effective. This means that the application of the blended learning model was an effective way to enhance students' achievement of mathematical concepts. After the N-Gain value was obtained, the next step was to conduct hypothesis testing using the t-test. At a $95 \%$ degree of confidence, as the $\mathrm{p}$ value $<0.05$, it can be concluded that there is a significant difference in the average scores between the blended learning and conventional learning groups. The t-test results are provided in Table 4.

Table-4. The t-test results.

\begin{tabular}{c|c|c|c}
\hline Data source & tcount & ttable & Sig. \\
\hline Experiment class & 5.904 & 2.002 & 00.00 \\
\hline Control Class & 17.05 & 2.0024 & 00.00 \\
\hline
\end{tabular}

Table 4 shows that, with a significance value of $<0.05$ because tcount $>$ ttable, Ho is rejected. It can therefore be concluded that there is a significant difference in the level of achievement of mathematical concepts between the experimental and the control class and that these significant differences in the average value are due to the difference in learning model. Based on the results above, it can be concluded that the blended learning model, applied in the experimental class, is more effective than the conventional learning model, applied in the control class, in improving students' achievement of mathematical concepts on the subject of trigonometry, and specifically the basic competencies of trigonometric ratios in right triangles and their contextual problems.

\section{Discussions}

Based on the findings of this study and the results of the experimental and control classes, the implementation of the blended learning model has been proven effective to enhance students' achievement of mathematical concepts. The blended learning model is an alternative learning model that can be used by teachers during trigonometry learning to improve the achievement of mathematical concepts. The effectiveness of the blended learning model was measured by means of the learning outcomes gap between the experimental and the control group. The findings indicate that there is a difference between the posttest scores of the experimental and the control groups, as well as the students' learning outcomes, with an average of $\geq 75$. This result agrees with the findings of Sjukur (2012), who concluded that there are differences in learning outcomes between students who are taught through blended learning and those taught only through conventional learning.

The majority of students who undertook blended learning obtained higher learning outcomes. Similarly, Lin, Tseng, and Chiang (2014) showed students' positive responses to mathematics learning using a blended learning model. Theoretically and empirically, the blended learning model can be categorized as a practical learning model due to its methods of implementation and learning management. The blended learning model applies e-learning principles, such as the use of computer and internet technology, to present a meaningful learning experience and to connect teachers and students through a virtual learning platform (Darmawan \& Wahyudin, 2018). E-learning serves to overcome certain limitations of both teachers and students, especially in terms of time, space, conditions, and circumstances. Teachers should be able to adjust to the application of Moodle-based e-learning in mathematics learning since it allows for various learning activities.

Our findings are consistent with the claim of Thirunarayanan, Bayo, and Slater (2010), who argued that online learning makes learning more effective and efficient. Keengwe (2012) also noted that the blended learning model will be more effective if it is integrated with other pedagogical methods, such as problem-based learning. Another finding of Tang and Chaw (2013) highlighted that the use of the blended learning model benefits students, especially its flexibility in terms of time, place, and accessibility. Tuomainen (2016) revealed that the blended learning model can enhance (1) students' enthusiasm for learning due to the comfort and flexibility in time management; (2) student's learning preferences; and (3) students' autonomy to be more independent and responsible with regard to their own learning. Moreover, Mozelius and Hettiarachchi (2017) point outed that a combination of face-to-face and online learning activities, or blended learning, is better than a single method. Likewise, Albhnsawy and Aliweh (2016) mentioned that blended learning activities offer many opportunities for teachers and students to receive feedback and exchange perspectives.

The blended learning model enables students to access various learning resources (Behjat et al., 2012). As explained by Wardani et al. (2018), the blended learning model can boost the attractiveness of the learning process and is very suitable to be applied in the $21^{\text {st }}$ century. According to Dziuban, Graham, Moskal, Norberg, and Sicilia (2018), the blended learning model can create an effective learning environment, efficient communication, better access, and good learning evaluation. The findings of Surjono et al. (2017) show that the application of blended learning provides more benefits to enhance students' achievement and active participation than traditional face-toface learning and that students have positive perceptions towards the application of blended learning. 


\section{Conclusion and Recommendation}

Based on the research findings, it can be concluded that blended learning is more effective for improving tenthgrade students' achievement of mathematics concepts than conventional learning, because the average score of the class with the blended learning model is higher than the minimum completeness criteria. There is also a significant gap between the learning outcomes, in terms of the achievement of mathematical concepts, of the blended learning class and the conventional class. The blended learning model is an alternative learning model that can be used by teachers to improve students' achievement of mathematical concepts. This blended learning model is based on the belief that students can best develop their thinking skills through problem-based learning with various sources of information, including face-to-face, online, and practical activities.

In light of the research findings, several suggestions can be put forward. This blended learning model should be popularized among mathematics teachers through a teacher forum so it can be more widely applied. This learning model is also very suitable for use by students who are often away from school, for instance due to sports competitions, so they can take part in independent learning. For schools with limited computer facilities, this learning model can still be applied using a smartphone. The results of this study also provides an empirical foundation that can be used as to further develop the blended learning model in future research. In addition, teachers can develop similar learning models to be applied to other competencies by referring to the procedures that were used in this study.

\section{References}

Albhnsawy, A., \& Aliweh, A. M. (2016). Enhancing student teachers' teaching skills through a blended learning approach. International Journal of Higher Education, 5(3), 131-136.Available at: https://doi.org/10.5430/ijhe.v5n3p131.

Arsyad, A. (2016). Learning media. Jakarta: Raja Grafindo Persada.

Behjat, F., Yamini, M., \& Bagheri, M. S. (2012). Blended learning: A ubiquitous learning environment for reading comprehension. International Journal of English Linguistics, 2(1), 97-106.Available at: https://doi.org/10.5539/ijel.v2n 1 p97.

Chasanah, C., Riyadi, R., \& Usodo, B. (2020). The effectiveness of learning models on written mathematical communication skills viewed from students' cognitive styles. European Journal of Educational Research, 9(3), 979- 994.Available at: https://doi.org/10.12973/eujer.9.3.979.

Cheung, W., \& Hew, K. (2011). Design and evaluation of two blended learning approaches. Australasian Journal of Educational Technology, 27(8), 1319-1337.Available at: https://doi.org/10.14742/ajet.896.

Darmawan, D. (2016). Development of E-learning theory and design. Bandung: Remaja Rosdakarya.

Darmawan, D., \& Wahyudin, D. (2018). Learning model in school. Bandung: PT Pemuda Rosdakarya.

Dziuban, C., Graham, C. R., Moskal, P. D., Norberg, A., \& Sicilia, N. (2018). Blended learning: The new normal and emerging technologies. International Journal of Educational Technology in Higher Education, 15(1), 1-16.Available at: https://doi.org/10.1186/s41239-0170087-5.

Hermino, A., \& Arifin, I. (2020). Contextual character education for students in the senior high school. European Journal of Educational Research, 9(3), 1009-1023.Available at: https://doi.org/10.12973/eu-jer.9.3.1009.

Jeffrey, L., Milne, J., Suddaby, G., \& Higgins, A. (2014). Blended learning: How teachers balance the blend of online and classroom components. Journal of Information Technology Education: Research, 13, 12 1-140.Available at: https://doi.org/10.28945/1968.

Johnson, J. D., \& Walker, M. (2011). Trigonometry students' knowing when to use handheld CAS technology to make sense of mathematics. Journal of Mathematical Sciences and Mathematics Education, 6(2), 17-33.

Kazu, I. Y., \& Demirkol, M. (2014). Effect of blended learning environment model on high school students' academic achievement. Turkish Online Journal of Educational Technology, 13(1), 78-87.

Keengwe, J. (2012). Blended learning in teacher preparation programs: A literature review. International Journal of Information and Communication Technology Education: An Official Publication of the Information Resources Management Association, 8(2), 479-493.

Kurniadi, A., Mardiyana, \& Riyadi. (2014). Mathematics learning experiments using the numbered heads together (NHT) cooperative learning model and the jigsaw type on the subject of trigonometry in class xi-science high school in Kudus Regency in terms of learning motivation of students in the 2013/2014 school year. Electronic Journal of Mathematics Learning, 2(7), 680-690.

Lin, Y. W., Tseng, C. L., \& Chiang, P. J. (2014). The effect of blended learning in mathematics course. Journal of Mathematics Science and Technology Education, 13(3), 741-770.Available at: https://doi.org/10.12973/eurasia.2017.00641 a.

Liu, G.-Z., \& Hwang, G.-J. (2010). A key step to understanding paradigm shifts in e-learning: Towards context-aware ubiquitous learning. British Journal of Educational Technology, 41(2), E1-E9.Available at: https://doi.org/10.1111/j.1467-8535.2009.00976.x.

Manfreda, K. V., \& Hodnik, T. (2021). Mathematical literacy from the perspective of solving contextual problems. European Journal of Educational Research, 1O(1), 467-483.Available at: https://doi.org/10.12973/eu-jer.10.1.467.

Miyaji, I., \& Fukui, H. (2020). Change in knowledge and awareness in teacher education on Satoyama environmental learning: Through a blend of learning spaces, methods and media. European Journal of Educational Research, 9(4), 1663-1674.Available at: https://doi.org/10.12973/eu-jer.9.4.1663.

Mozelius, P., \& Hettiarachchi, E. (2017). Critical factors for implementing blended learning in higher education. International Journal of Information and Communication Technologies in Education, 6(1), 4-18.

Ramadhan, R., Chaeruman, U. A., \& Kustandi, C. (2018). Development of blended learning at the State University of Jakarta. Journal of Innovative Learning, 1(1), 37-48.

Retnawati, H., Kartowagiran, B., Hadi, S., \& Hidayati, K. (2011). Identification of students' difficulties in learning mathematics and science in elementary schools. Journal of Education, 41(2), 162-174.

Ross, J. A., \& Bruce, C. (2009). Student achievement effects of technology-supported remediation of understanding of fractions. International Journal of Mathematical Education in Science and Technology, 40(6), 713-727.Available at:

Sadiq, F. (2014). Learning mathematics: How to improve students' thinking skills. Yogyakarta: Graha Ilmu.

Saka, A. O. (2021). Can teacher collaboration improve students' academic achievement in junior secondary mathematics. Asian Journal of University Education, 17(1), 33-46.Available at: https://doi.org/10.24191/ajue.v 17i1.8727.

Singhal, D. (2017). Understanding student- centered learning and philosophies of teaching practices. International Journal of Scientific Research and Management, 5(2).Available at: https://doi.org/10.18535/ijsrm/v5i2.02.

Sjukur. (2012). The effect of blended learning on learning motivation and student learning outcomes at the SMK level. Journal of Vocational Education, 2(3), 368-378

Suartama, I. K., Triwahyuni, E., Abbas, S., Hastuti, W. D., Usman, M., Subiyantoro, S., \& Salehudin, M. (2020). Development of e-learning oriented inquiry learning based on character education in multimedia course. European Journal of Educational Research, 9(4), 15911603.Available at: https://doi.org/10.12973/eu-jer.9.4.1591.

Sugiyono. (2015). Educational research methods. Yogyakarta: Alphabeta.

Surjono, H. D., Muhtadi, A., \& Wahyuningsih, D. (2017). The implementation of blended learning in multimedia courses for undergraduate students in Indonesia. International Journal of Information and Education Technology, 7(10), 783-786.Available at: https://doi.org/10.18178/ijiet.2017.7.10.972.

Suyanto, \& Asep, J. (2013). Become a professional teacher; strategy to improve teacher qualification and quality in the global Era. Jakarta: Erlangga.

Taber, K. S. (2018). The use of Cronbach's alpha when developing and reporting research instruments in science education. Research in Science Education, 48(6), 1273-1296.Available at: https://doi.org/10.1007/s11165-016-9602-2. 
Tang, C., \& Chaw, L. (2013). Readiness for blended learning: Understanding attitude of university students. International Journal of Cyber Society and Education, 6(2), 79-100.Available at: https://doi.org/10.7903/ijcse.1086.

Thirunarayanan, M. O., Bayo, I., \& Slater, R. (2010). Students' content preferences for taking online courses. International Journal of Instructional Technology and Distance Learning, 7(7), 1-57.

Tican, C., \& Deniz, S. (2019). Pre-service teachers' opinions about the use of 21 st century learner and 21 st century teacher skills. European Journal of Educational Research, 8(1), 181-197.Available at: https://doi.org/10.12973/eu-jer.8.1.181.

Tohir, M., Maswar, M., Atikurrahman, M., Saiful, S., \& Pradita, D. A. R. (2020). Prospective teachers' expectations of students' mathematical thinking processes in solving problems. European Journal of Educational Research, 9(4), 1735-1748.Available at: https://doi.org/10.12973/eu-jer.9.4.1735.

Tuomainen, S. (2016). A blended learning approach to academic writing and presentation skills. International Journal on Language, Literature and Culture in Education, 3(2), 33-55.Available at: https://doi.org/10.1515/llce-2016-0009.

Uz, R., \& Uzun, A. (2018). The influence of blended learning environment on self-regulated and self-directed learning skills of learners. European Journal of Educational Research, 7(4), 877-886.Available at: https://doi.org/10.12973/eu-jer.7.4.877.

Wardani, D. N., Toenliou, A. J. E., \& Wedi, A. (2018). The attraction of learning in the 21 st century era with blended learning. Journal of Educational Technology Studies, 1(1), 13-18.

Waskitoningtyas, R. S. (2016). Analysis of learning difficulties in mathematics for fifth grade elementary school students in Balikpapan in the time unit material for the 2015/2016 academic year. Scientific Journal of Mathematics Education, 5(1), $24-32$. 